\title{
THE EFFECT OF CAREER DEVELOPMENT AND MOTIVATION ON EMPLOYEE PERFORMANCE THROUGH JOB SATISFACTION IN PT JABAR JAYA PERKASA
}

\author{
Nita Tri Febrianti, Suharto ${ }^{2}$, Wachyudi ${ }^{3}$ \\ ${ }^{1}$ Student Master of Management, Universitas Krisnadwipayana \\ Campus Unkris Jatiwaringin, PO BOX 7774/Jat CM Jakarta 13077 \\ Indonesia \\ ${ }^{2}$ Associate Professor, Universitas Krisnadwipayana \\ Campus Unkris Jatiwaringin PO BOX 7774/Jat CM Jakarta 13077 \\ Indonesia \\ ${ }^{3}$ Lecturer and Researcher, Universitas Krisnadwipayana \\ Campus Unkris Jatiwaringin PO BOX 7774/Jat CM Jakarta 13077 \\ Indonesia
}

\begin{abstract}
A R T I C L E I N F O
Article history: Article

Received

Revised

Accepted: September, 2020

DOI: $10.47742 / i j b s s r . v 1 n 2 p 3$
\end{abstract}

\begin{abstract}
A B S T R A C T
This study aims to: 1) To find out and analyze the effect of career development and motivation on job satisfaction, 2) To know and analyze the effect of career development and motivation on employee performance, 3) To find out and analyze the effect of job satisfaction on employee performance, 4) To find out and analyze the influence of career development and motivation on employee performance through job satisfaction PT. Jabar Jaya Perkasa. The study was conducted at PT. Jabar Jaya Perkasa with a research sample of 58 respondents. The sampling technique uses saturated samples. The data analysis method uses descriptive analysis and quantitative analysis with path analysis.

The results showed that: 1) there was an influence on career development and motivation on job satisfaction, 2) there was an influence on career development and motivation on employee performance, 3) there was an effect on job satisfaction on employee performance and 4) there was no influence on career development and motivation on performance employees through job satisfaction PT. Jabar Jaya Perkasa. This means that the direct effect is greater than the indirect effect, the variable job satisfaction cannot mediate between motivation and job satisfaction on employee performance at PT. Jabar Jaya Perkasa.
\end{abstract}

Keywords : Career Development, Motivation, Job Satisfaction and Employee Performance

\section{Introduction}

Human resources are now increasingly playing a major role in the success of an organization or government agency. Many government organizations or agencies realize that the human element in an organization or government agency can provide a competitive advantage. They make strategies and innovations in achieving organizational goals. Therefore, human resources are one of the most vital elements for government organizations or agencies. Because its role to implement the strategy is very important, namely as an executing subject of organizational strategy. With the existence of human resources, it can provide quality results, is the hope of government organizations or agencies, for organizations or government agencies that can achieve optimal performance as desired by the organization, both by individual employees and groups in government organizations or agencies so that the objectives will be can be achieved and realized. With this, they have the potential, such as expertise, thoughts, etc. in an organization or government agency, their potential can be utilized and optimized to achieve goals. People who occupy positions in an organization or government agency either as members or leaders are the most important factors because they are related to one another in every organization or institution, both government and private. The success of an organization or government agency is influenced by human factors as those who carry out or carry out the work done.

One way that an organization or government agency can take care of and maintain its human resources is by looking at the career development provided to employees. According to Andoko in Megita (2014), career development is personal improvements that a person makes to achieve a career plan. Employees need work that can be done seriously. Job is an employment position in a position, maybe we can do a lot of work in a position because that work generates the money we need to fulfill our daily needs or to do and buy things we like. Our job is our job, our profession, which may change over time during our lifetime. Career is our entire work life. Corey \& Corey (2006: 9) suggest that each career path we take may consist of one or several positions, which increase with our work experience.

Every employee who works needs a job and career development so that employees can be well-motivated at work. The clear career development of the company has an impact on increasing this motivation. Career development includes activities to prepare an individual for advancement in the planned career path. So from the definition of career development above, it can be concluded that career development is an activity to 
prepare individuals to develop themselves through a planned career path. The better the understanding of career development and its implementation, it is hoped that employee performance will also be even greater.

Apart from seeing the career development given to employees, another factor that must be considered is work motivation. Work motivation according to Suwanto and Donni Juni Priansa (2011: 171) states motivation. comes from the Latin word (movere) which means impulse, driving force, or force that causes an action or deed. Motivate the work of subordinates so that they are willing to work productively in achieving and realizing predetermined goals. The motivation that is in a person is a power that will create good behavior in achieving selfsatisfaction and lead positively to the object being the goal.

Motivation is a condition that encourages someone to do, behave and behave to achieve the desired goals. Motivation will be positive when someone feels happy and interested in work, but motivation becomes negative when someone feels bored and depressed. Motivation becomes a motivation for someone to carry out an activity to get the best results as expected. Therefore, it is not surprising that employees who have very high work motivation usually have high performance as well. For this reason, employees need to generate work motivation to produce a good performance as expected.

Someone's satisfaction at work also plays a role in producing high performance. The higher the level of individual satisfaction at work, the greater the individual's performance will be. Another factor that needs to be considered in improving individual performance is work discipline. Discipline plays an important role in the success of one's work. As a company engaged in engineering, PT. Bambu Tirta Engineering must be able to compete with other companies. One of the strengths of the company is the development of its human resources to produce a good performance. To be able to produce a good performance, management must pay attention to motivation, satisfaction and work discipline of employees at the company.

\section{Literature Review}

\section{Employee Performance}

Performance is the result of the work or activities of an employee in quality and quantity in an organization to achieve goals in carrying out the tasks and jobs assigned to him. Rivai (2005: 309) states that performance is a real behavior that is displayed by each person as a work achievement produced by employees following their role in the company.

Meanwhile, according to Mathis (2002: 78) which is an indicator in measuring employee performance or achievement are as follows:

1. Work quantity, namely the volume of work produced under normal conditions.

2. Quality of work, which can be in the form of neatness, accuracy and linkage of results without neglecting the volume of work. http://iarpnet.org/

3. Time utilization, namely the use of the working period adjusted to the policy of the company or government institution.

4. Cooperation, namely the ability to handle relationships with other people at work.

Performance is the result of work in quality and quantity that can be achieved by an employee in carrying out tasks following the responsibilities assigned to him. The definition of performance according to Kusriyanto in Mangkunegara (2005: 9 ) is a comparison of the results achieved with the participation of labor per unit time (usually per hour). Meanwhile, according to Mangkunegara (2005: 9), employee performance (work performance) is the quality and quantity of work achieved by an employee in carrying out his duties according to the responsibilities assigned to him. Therefore, it can be concluded that HR performance is work performance, or output, both the quality and quantity achieved by HR per unit period in carrying out its work tasks following the responsibilities assigned to it. Performance appraisal is an effort made by the leader to assess the work results of his subordinates.

According to Megginson in Mangkunegara, (2005: 10), job performance appraisal is a process used by leaders to determine whether an employee is doing his job following his duties and responsibilities. Furthermore, Sikula in Mangkunegara, (2005: 10) suggests that employee appraisal is a systematic evaluation of the work of employees and the potential that can be developed.

Assessment in the process of interpreting or determining the value, quality, or status of several objects, people, or things. According to Handoko (2001: 235), job performance appraisal is a process through which organizations evaluate or assess employee performance. This activity can improve personnel decisions and provide feedback to employees about the performance of their work.

Based on the opinion of some of these experts, it can be concluded that the assessment of work performance (performance) is an assessment that is carried out systematically to determine the results of employee work and organizational performance. It is also to determine job training appropriately, to provide a better response in the future and as a basis for determining policies in terms of promotion and determination of rewards. The purpose of job performance appraisal (performance) is to improve or enhance the organizational performance of the organization's HR.

\section{Career Development}

Work is an employment position in a position, maybe we can do a lot of work in a position because that work generates the money we need to fulfill our daily needs or to do and buy things we like. The position is our job, our profession., which may change for some time throughout our lives. Career is our entire work life. Corey \& Corey (2006: 9) suggest that each career path we take may consist of one or several positions, which increase with our work experience. Wilson (2006: 27) defines a career as 


\section{Vol: 1, Issue: 2} October $/ 2020$

https://ijbssrnet.com/index.php/ijbssr DOI: $10.47742 /$ ijbssr.v1n2p3

the total work we do during our life, whether paid or not. Furthermore, Collin (in Kristanto, 2003: 24) adds that careers arise as a result of a person's interactions with organizations and their social environment.

Career development according to Mondy (2008: 14) includes activities to prepare an individual for the advancement of a planned career path. So from the definition of career development above, it can be concluded that career development is an activity to prepare individuals to develop themselves through a planned career path.

Mondy (2008: 14) describes several principles in career development, including the following:

1. The job itself has a very big influence on career development. If every job day presents a different challenge, what is learned on the job is far more important than formal development planning activities.

2. The form of skill development required is determined by the specific job request. The skills needed to become a supervisor will be different from the skills needed to become a middle manager.

3. The development will occur only if an individual has not acquired skills that are following the demands of the job. If these goals are further developed by an individual, individuals who already have the skills required of the job will occupy a new job.

4. Time spent on development can be reduced by identifying a series of rational individual job placements.

Career development includes career planning and career management. Understanding career development in an organization requires an examination of two processes, namely how each plan and implements his or her career goals (career planning) and how the organization designs and implements career development/career management programs.

Based on the above understanding, there are different responsibilities between individuals/employees and organizations in managing careers. Career planning emphasizes more on individuals, which includes: self-assessment, career counseling, job choices, and organizational choices, while career management emphasizes more on organizational interests, namely: recruitment, selection, performance appraisal, training and development, assessment center, expertise, succession planning, and placement outside (employed in fostered subsidiaries).

\section{Motivation}

Motivation is an impulse that causes a person to do an action to achieve a certain goal. Motivation comes from the word motive which means "impulse" or stimulation or "driving force" that is within a person. According to Weiner (1990) quoted by Elliot et al. (2000), motivation is defined as an internal condition that arouses us to act, encourages us to achieve certain goals, and keeps us interested in certain activities.
According to Uno (2007), motivation can be interpreted as internal and external encouragement in a person as indicated by their existence; passions and interests; urges and needs; hopes and ideals; appreciation and respect. According to Weiner (1990) quoted by Elliot et al. (2000), motivation is defined as an internal condition that arouses us to act, encourages us to achieve certain goals, and keeps us interested in certain activities. Motivation is the impact of a person's interaction with the situation he is facing (Siagian, 2004). Motivation becomes a force, energy or power, or a complex situation and readiness in the individual to move towards a certain goal, whether consciously or unconsciously (Makmun, 2003).

Motivation is also defined as a power resource that drives and controls human behavior. Motivation is an effort that can encourage someone to take the desired action, while motive is the power of a person to act. The term motivation comes from the Latin word mover which means to move or move. Because a person's behavior tends to be goal-oriented and driven by the desire to achieve certain goals.

Employee motivation is no less important in contributing to the company. Motivation is the willingness to put more effort into achieving organizational goals, which is caused by a willingness to satisfy individual needs (Robbins, 1996).

With the right motivation, employees will be motivated to do their best in carrying out their duties because they believe that with the success of the organization in achieving its goals and objectives, the personal interests of the members of the organization will also be included. High motivation will create a commitment to what is their responsibility in completing each job (McNeese-Smith et al, 1993).

\section{Job Satisfaction}

Job satisfaction is a feeling of pleasure or disappointment for someone who arises after comparing his perceptions or impressions of job satisfaction or work results. Meanwhile, Oliver defines satisfaction as the level of a person's feelings after comparing job satisfaction / perceived results with expectations (Handoko, 2003). So, the level of satisfaction is a function of the difference between perceived job satisfaction and expectations. If job satisfaction is below expectations, then employees will be disappointed, if job satisfaction is as expected, employees will be satisfied.

Employee job satisfaction must be created as well as possible so that employee morale, dedication, love and discipline increased. Job satisfaction is a pleasant emotional attitude and loves his job. This attitude is reflected by work morale, discipline, and work performance. Job satisfaction is enjoyed at work, outside work and a combination of inside and outside work (Hasibuan; 2007: 202).

Employee job satisfaction is influenced by the following factors (Hasibuan; 2007: 203):

1. Fair and proper remuneration.

2. The right placement according to expertise.

3. The weight of work. 
http://iarpnet.org/

4. Work atmosphere and environment.

5. Equipment that supports the implementation of work.

6. The attitude of the leader in his leadership.

7. The nature of work is monotonous or not.

8. Work Discipline
Vol: 1, Issue: 2

October $/ 2020$

https://ijbssrnet.com/index.php/ijbssr DOI: 10.47742/ijbssr.v1n2p3

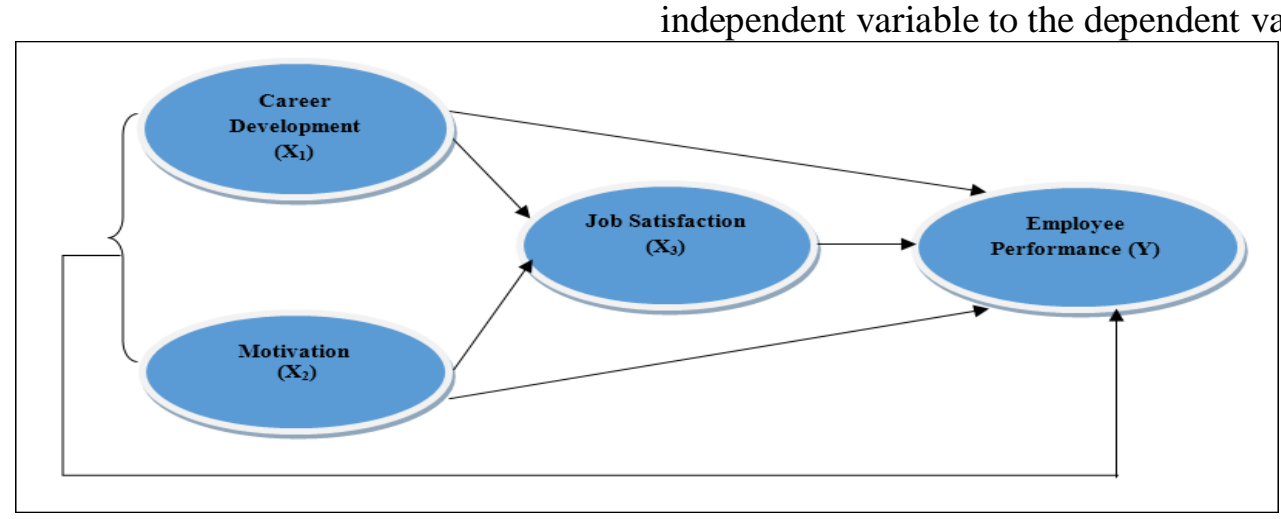

Figure 1. Concept Model

\section{Population and Sample}

The population is a generalization area consisting of objects/subjects that have certain quantities and characteristics set by the researcher for the study and then draw conclusions (Sugiyono, 2005). The sample is a part of the population to represent the entire population (Surakhmad, 1990). The sample used by the authors in this study were company employees.

The total number of employees is 58 people. The total number of works is assumed to be entirely in data analysis as the research sample. The sampling technique uses saturated samples.

\section{Research Methods \\ Research Objects \\ Pesona Anggrek Housing Block G2 No. 09 Rt 008 Rw 024 Bekasi Utara City of Bekasi. \\ Research Design}

This study uses an explanatory analysis approach. This means that each variable presented in the hypothesis will be observed through testing the causal relationship of the independent variable to the dependent variable.

Table 1. Results of the Simultaneous Test of Career Development and Motivation on Job Satisfaction

\begin{tabular}{llrrr}
\hline Model & $\mathrm{R}$ & $\begin{array}{c}\mathrm{R} \\
\text { Square }\end{array}$ & $\begin{array}{c}\text { Adjusted R } \\
\text { Square }\end{array}$ & $\begin{array}{c}\text { Std. Error of the } \\
\text { Estimate }\end{array}$ \\
\hline 1 & $.782^{\mathrm{a}}$ & .611 & .597 & 1.91736 \\
\hline
\end{tabular}

a. Predictors: (Constant), X2, X1

b. Dependent Variable: X3

The samples included are company employees who work without paying attention to years of service and education level.

Research Results and Discussion

1. Analysis of the Influence of Career Development and Motivation on Job Satisfaction

According to Ghozali (2006: 211), the path coefficient uses standardized regression coefficients. The results of the regression analysis of the effect of career development and motivation on job satisfaction can be seen in the table below:

Source: Primary data processed, 2020

Table 1, shows the value of R2 (R Square) of 0.611. The explained by career development and motivation. Magnitude: value of $\mathrm{R} 2$ is used in calculating the value of the e1 coefficient. The coefficient of e1 $=0.624$

The coefficient e1 is a variant of job satisfaction that is not

Table 2. Job Satisfaction Regression Analysis

\begin{tabular}{|c|c|c|c|c|c|}
\hline \multirow[b]{2}{*}{ Model } & \multicolumn{2}{|c|}{$\begin{array}{c}\text { Unstandardized } \\
\text { Coefficients }\end{array}$} & \multirow{2}{*}{$\begin{array}{c}\text { Standardized } \\
\text { Coefficients } \\
\text { Beta }\end{array}$} & \multirow[b]{2}{*}{$\mathrm{t}$} & \multirow[b]{2}{*}{ Sig. } \\
\hline & B & Std. Error & & & \\
\hline 1 (Constant) & 3.659 & 1.411 & & 2.593 & .012 \\
\hline $\mathrm{X} 1$ & .203 & .125 & .203 & 2.023 & .002 \\
\hline $\mathrm{X} 2$ & .786 & .150 & .785 & 5.245 & .000 \\
\hline
\end{tabular}

Based on Table 2, it can be seen that the regression equation is as follows:

$$
\begin{array}{ll}
X_{3}= & b_{1} X_{1}+b_{2} X_{2}+e_{1} \\
X_{3}= & 0,203 X_{1}+0,785 X_{2}+0,624 e_{1}
\end{array}
$$


The equation shows that:

- Every time there is an increase in 1 career development, an increase in job satisfaction will be followed by 0.203 .

- Every increase of 1 motivation unit will be followed by an increase in job satisfaction of 0.785 .
Vol: 1, Issue: 2

October $/ 2020$

https://ijbssrnet.com/index.php/ijbssr DOI: $10.47742 /$ ijbssr.v1n2p3

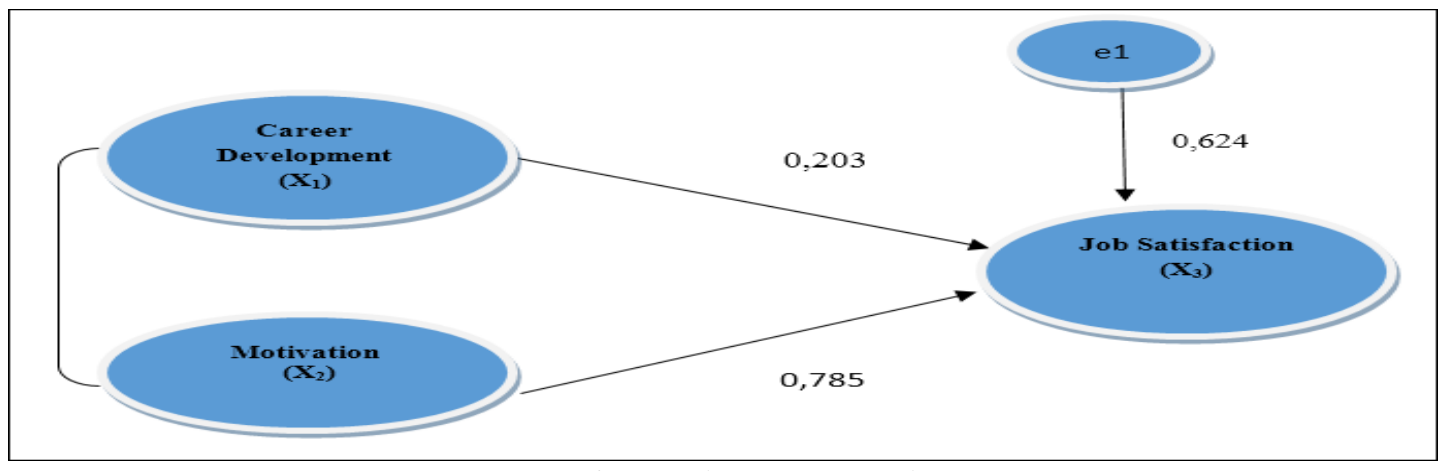

Source: Primary data processed, 2020

Figure 2. Substructure Equations 1

2. Analysis of the Influence of Career Development, Motivation and Job Satisfaction on Employee Performance

Table 3. Results of the Simultaneous Test of Career Development, Motivation, and Job Satisfaction on Employee Performance

Model Summary ${ }^{\text {b }}$

\begin{tabular}{lrrrrr}
\hline Model & R & R Square & $\begin{array}{c}\text { Adjusted R } \\
\text { Square }\end{array}$ & $\begin{array}{c}\text { Std. Error of the } \\
\text { Estimate }\end{array}$ & Durbin-Watson \\
\hline 1 & $.817^{\text {a }}$ & .668 & .649 & 2.77541 & 1.928
\end{tabular}

a. Predictors: (Constant), X3, X1, X2

b. Dependent Variable: $\mathrm{Y}$

Source: Primary data processed, 2020

Table 3 shows the R2 (R Square) value of 0.668. This R2 explained by career development, motivation and job value is used in calculating the value of the e 2 coefficient. The satisfaction. Magnitude: The coefficient of e $2=0.576$ coefficient $\mathrm{e} 2$ is a variant of employee performance that is not

Table 4. Employee Performance Regression Analysis

\begin{tabular}{|c|c|c|c|c|c|c|}
\hline \multirow{2}{*}{\multicolumn{2}{|c|}{ Model }} & \multicolumn{2}{|c|}{$\begin{array}{l}\text { Unstandardized } \\
\text { Coefficients }\end{array}$} & \multirow{2}{*}{$\begin{array}{c}\text { Standardized } \\
\text { Coefficients } \\
\text { Beta } \\
\end{array}$} & \multirow[b]{2}{*}{$\mathrm{t}$} & \multirow[b]{2}{*}{ Sig. } \\
\hline & & B & Std. Error & & & \\
\hline \multirow[t]{4}{*}{1} & (Constant) & 2.649 & 2.164 & & 1.224 & .226 \\
\hline & $\mathrm{X} 1$ & .638 & .181 & .493 & 3.534 & .001 \\
\hline & $\mathrm{X} 2$ & .144 & .266 & .093 & 2.541 & .001 \\
\hline & X3 & .771 & .195 & .497 & 3.950 & .000 \\
\hline
\end{tabular}

Source: Primary data processed, 2020

Based on Table 4, it can be seen that the regression equation is as follows:

$\mathrm{Y}=\mathrm{b}_{1} \mathrm{X}_{1}+\mathrm{b}_{2} \mathrm{X}_{2}+\mathrm{b}_{3} \mathrm{X}_{3}+\mathrm{e}_{2}$

$Y=0,493 X_{1}+0,093 X_{2}+0,497 X_{3}+0,576 e_{2}$

The equation shows that:
- Every time there is an increase in 1 career development unit, an increase in employee performance will be followed by 0.493 .

- Every time there is an increase of 1 unit of motivation, will be followed by an increase in employee performance by 0.093 . 
- Every time there is an increase of 1 unit of job satisfaction, will be followed by an increase in employee performance by 0.576 .

So from equation (2) it can be seen that if career development is done, employee performance will increase. If
Vol: 1, Issue: 2

October $/ 2020$

https://ijbssrnet.com/index.php/ijbssr DOI: $10.47742 /$ ijbssr.v1n2p3

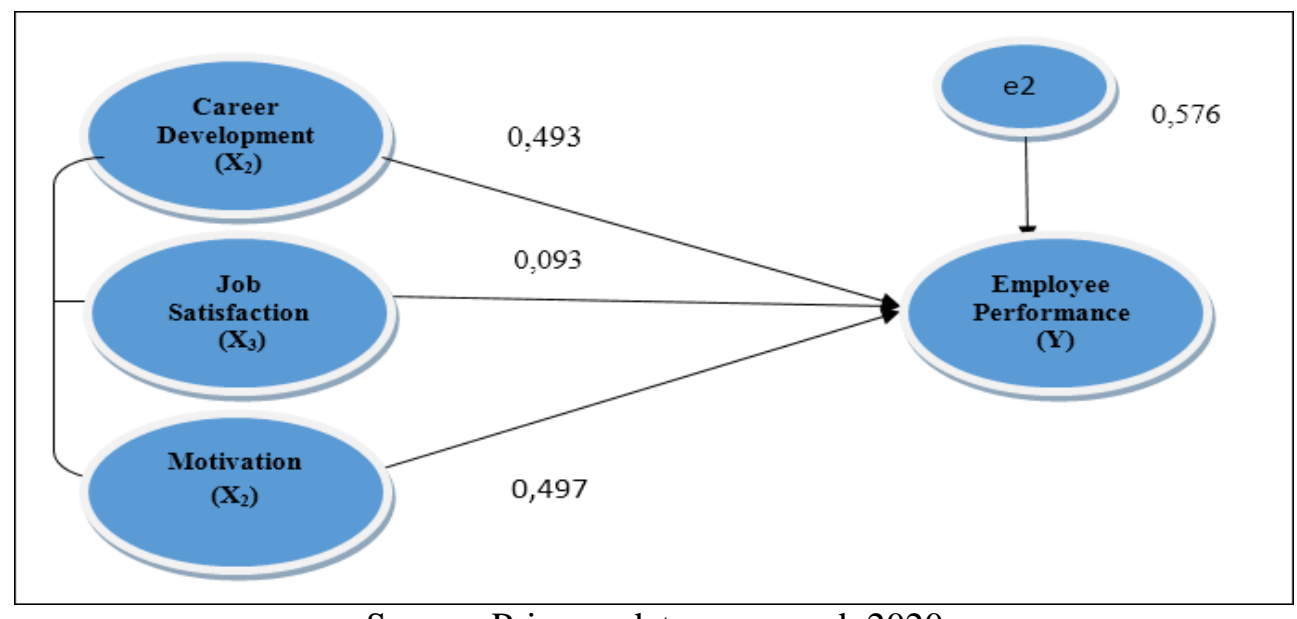

Source: Primary data processed, 2020

Figure 3. Substructure Equations 1 I

Based on equations (1) and (2), a path analysis model is obtained as follows:

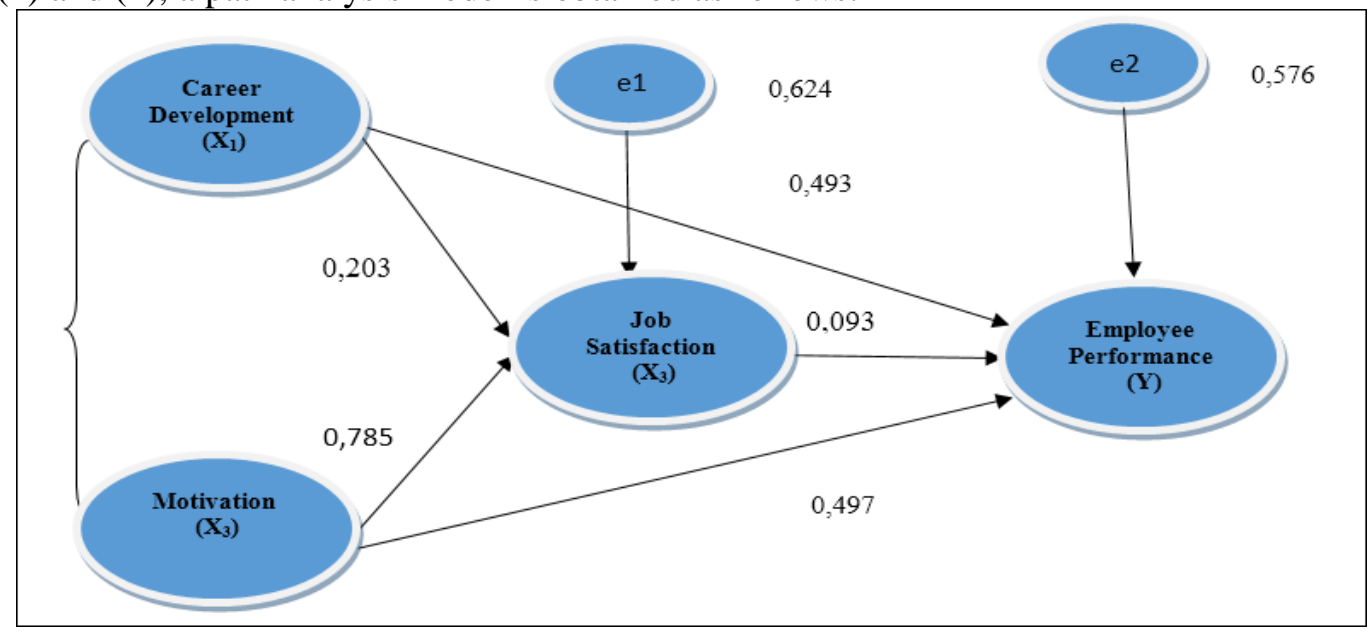

Source: Primary data processed, 2020

Figure 4. Path Analysis

\section{Hypothesis Test}

To find out this, it is necessary to use the t-test. The following is 1. It is suspected that there is an influence of career a test of each variable: development and motivation on job satisfaction

Table 5. T-Test Results in Effect of Career Development and Motivation on Job Satisfaction

\begin{tabular}{|c|c|c|c|c|c|}
\hline \multirow[b]{2}{*}{ Model } & \multicolumn{2}{|c|}{$\begin{array}{l}\text { Unstandardized } \\
\text { Coefficients }\end{array}$} & \multirow{2}{*}{$\begin{array}{c}\text { Standardized } \\
\text { Coefficients }\end{array}$} & \multirow[b]{2}{*}{$\mathrm{t}$} & \multirow[b]{2}{*}{ Sig. } \\
\hline & $\mathrm{B}$ & Std. Error & & & \\
\hline $1 \quad$ (Constant) & 3.659 & 1.411 & & 2.593 & .012 \\
\hline $\mathrm{X} 1$ & .003 & .125 & .203 & 2.023 & .000 \\
\hline $\mathrm{X} 2$ & .786 & .150 & .785 & 5.245 & .000 \\
\hline
\end{tabular}

Source: Primary data processed, 2020 
From Table 5, it is found that the t-count value of the motivation affect job satisfaction. Thus the first hypothesis is career development variable is 2.023 , while the t-table value is tested and proven. 1.663 and the t-count value for the motivation variable is 5.245 , while the $\mathrm{t}$-table value is 1.663 . Thus $\mathrm{t}$-count $>\mathrm{t}$-table (2.023> $1.663)$ and $(2.023>1.663)$, thus $\mathrm{H} 0$ is rejected and $\mathrm{H} 1$ is accepted Vol: 1, Issue: 2 October/2020

https://ijbssrnet.com/index.php/ijbssr DOI: $10.47742 /$ ijbssr.v1n2p3

at the real level. This concludes that career development and

Table 6. T-Test Results in Effect of Career Development and Motivation on Employee Performance

\begin{tabular}{|c|c|c|c|c|c|}
\hline \multirow[b]{2}{*}{ Model } & \multicolumn{2}{|c|}{$\begin{array}{c}\text { Unstandardized } \\
\text { Coefficients }\end{array}$} & \multirow{2}{*}{$\begin{array}{c}\text { Standardized } \\
\text { Coefficients } \\
\text { Beta } \\
\end{array}$} & \multirow[b]{2}{*}{$\mathrm{t}$} & \multirow[b]{2}{*}{ Sig. } \\
\hline & $\mathrm{B}$ & Std. Error & & & \\
\hline 1 (Constant) & 5.470 & 2.298 & & 2.380 & .021 \\
\hline $\mathrm{X} 1$ & .636 & .203 & .492 & 3.131 & .003 \\
\hline $\mathrm{X} 2$ & .462 & .244 & .297 & 1.894 & .064 \\
\hline
\end{tabular}

Source: Primary data processed, 2020

The t-test results for the career development variable obtained the $\mathrm{t}$-count value $=3.131$ and the $\mathrm{t}$-table value of 1.663 and the motivation variable obtained the $t$-count value of 1.894 , and the $\mathrm{t}$-table value of 1.663 . This means that $\mathrm{t}$-count $>\mathrm{t}$-table (3.131> 1.663) and (1.894>1.663), which means that $\mathrm{HO}$ is rejected and $\mathrm{H} 1$ is accepted. This concludes that career development and motivation affect employee performance. Thus, the second hypothesis is tested and proven.
2. It is suspected that there is an effect of career development and motivation on employee performance

To test the effect of career development and motivation on employee performance, the t-test is used. The following are the results of the t-test:

Table 7. The Effect of Job Satisfaction on Employee Performance

\begin{tabular}{|c|c|c|c|c|c|}
\hline \multirow[b]{2}{*}{ Model } & \multicolumn{2}{|c|}{$\begin{array}{l}\text { Unstandardized } \\
\text { Coefficients }\end{array}$} & \multirow{2}{*}{$\begin{array}{c}\text { Standardized } \\
\text { Coefficients } \\
\text { Beta } \\
\end{array}$} & \multirow[b]{2}{*}{$\mathrm{t}$} & \multirow[b]{2}{*}{ Sig. } \\
\hline & $\mathrm{B}$ & Std. Error & & & \\
\hline 1 (Constant) & 4.208 & 2.336 & & 1.801 & .077 \\
\hline $\mathrm{X} 3$ & 1.153 & .139 & .743 & 8.308 & .000 \\
\hline
\end{tabular}

Source: Primary data processed, 2020

The results of the t-test for the variable job satisfaction obtained a value of $t$ count of 8.308 and $t$-table of 1.663. This means that $\mathrm{t}$-count $>\mathrm{t}$-table $(8.308>1.663)$, which means that $\mathrm{H} 0$ is rejected and $\mathrm{H} 1$ is accepted. This concludes that job satisfaction affects employee performance. Thus the third hypothesis is tested and proven.

4.It is suspected that there is an influence of career development and motivation on employee performance through job satisfaction

$\mathrm{X}_{1} \rightarrow \mathrm{X}_{3} \rightarrow \mathrm{Y}=\left(\rho \mathrm{x}_{3} \mathrm{X}_{1}\right) \mathrm{x}\left(\rho \mathrm{yx}_{3}\right)=0,203 \mathrm{x} 0,093=0,012$

$\mathrm{X}_{2} \rightarrow \mathrm{X}_{3} \rightarrow \mathrm{Y}=\left(\rho \mathrm{x}_{3} \mathrm{X}_{2}\right) \mathrm{x}\left(\rho \mathrm{yx}_{3}\right)=0,785 \times 0,093=0,073$

In the career development variable, the indirect effect value is obtained from the path coefficient value $\rho \times 3 \times 1$ multiplied by the path coefficient value $\rho y x 3$. The multiplication result shows that the value of the indirect effect coefficient is smaller than the value of the direct effect coefficient.

In the motivation variable, the indirect effect value is obtained from the path coefficient value $\rho \times 3 \times 2$ multiplied by the path coefficient value $\rho y x 3$. The multiplication result shows that the value of the indirect effect coefficient is smaller than the value
3. It is suspected that there is an effect of job satisfaction on employee performance

To test the effect of job satisfaction on employee performance, a t-test is used. The following are the results of the t-test: of the direct effect coefficient. This shows that job satisfaction cannot mediate, namely career development and motivation in influencing employee performance.

\section{Total Effect}

- The influence of career development on employee performance through job satisfaction

$\mathrm{X} 1 \rightarrow \mathrm{X} 3 \rightarrow \mathrm{Y}=\rho \mathrm{yx} 1+\{(\rho \mathrm{x} 3 \mathrm{x} 1) \mathrm{x}(\rho \mathrm{yx} 3)\}=0.203+0.093$ $=0.296$

- The total influence that arises from career development on employee performance through job satisfaction is 0.296 .

The influence of work motivation on employee performance through job satisfaction

$\mathrm{X} 2 \rightarrow \mathrm{X} 3 \rightarrow \mathrm{Y}=\rho \mathrm{yx} 2+\{(\rho \times 3 \times 2) \times(\rho \mathrm{yx} 3)\}=0.785+0.093$ $=0.878$

- The total effect of work motivation on employee performance through job satisfaction is 0.878 .

Effect of career development on employee performance $\mathrm{X} 1 \rightarrow \mathrm{Y}=\rho \mathrm{yx} 1=0.493$ 
- The total influence arising from career development on employee performance is 0.493

- The influence of motivation on employee performance $\mathrm{X} 2 \rightarrow \mathrm{Y}=\rho \mathrm{yx} 2=0.497$

- The total influence arising from motivation on employee performance is 0.497

- $\quad$ Effect of job satisfaction on employee performance $\mathrm{X} 3 \rightarrow \mathrm{Y}=\rho \mathrm{yx} 3=0.093$

- The total effect of job satisfaction on employee performance is 0.093 .

- The Effect of Residual Coefficient Variables on job satisfaction

The coefficient of e $1=0.624$

- The Effect of Residual Coefficient Variables on employee performance

The coefficient of e $2=0.576$

\section{Discussion}

\section{Effect of Career Development and Motivation on Job Satisfaction}

Based on the analysis of career development variable descriptions, it shows that the employee placement indicator has the largest contribution to the formation of career development variables, namely employees are placed following education and job expertise. The motivation variable shows that the indicator of independent work provides the greatest contribution to the formation of the motivation variable, namely employees are not dependent on their work on their co-workers. Based on the analysis of job satisfaction variable descriptions, it shows that the dedication to work indicator gives the greatest value to the formation of job satisfaction variables, namely employees have high dedication in carrying out work so that every job is considered special.

Based on the results of the path analysis, it shows that career development and motivation have an impact on increasing job satisfaction. The results of the study are in line with research conducted by Fauziah Nami Nasution, Emmy Mariatin, Siti Zahreni (2018), Ni Luh Putu Ariesta Angga Dewi, I Wayan Mudiartha Utama (2016), Ichlapio Fitrianto, Hasmin, Akmal Umar (2016), Rizki Novriyanti Zahara, Hajan Hidayat (2017), Cedaryana, Muchlis R. Luddin, Yetti Supriyati (2018), and Natalia Susanto, (2019).

\section{Effect of Career Development and Motivation on Employee Performance}

Based on the analysis of career development variable descriptions, it shows that the employee placement indicator has the largest contribution to the formation of career development variables, namely employees are placed following education and job expertise. The motivation variable shows that the indicator of independent work provides the greatest contribution to the formation of the motivation variable, namely employees are not dependent on their work on their co-workers.

Based on the results of the path analysis, it shows that career development and motivation have an impact on improving employee performance. The results of the study are in line with the research conducted by Ichlapio Fitrianto, Hasmin, Akmal Umar (2016), Rizki Novriyanti Zahara, Hajan Hidayat (2017), Cedaryana, Muchlis R. Luddin, Yetti Supriyati (2018).

\section{The Effect of Job Satisfaction on Employee}

\section{Performance}

Based on the results of the descriptive analysis of the employee performance variables, it shows that the initiative indicators make a major contribution to the formation of employee performance variables, namely employees have a high initiative attitude at work. The job satisfaction variable shows that the dedication to work indicator gives the greatest value to the formation of job satisfaction variables, namely employees have high dedication in carrying out work so that every job is considered special.

Based on the results of path analysis, it shows that job satisfaction has an impact on improving employee performance. The results of the study are in line with research conducted by Ichlapio Fitrianto, Hasmin, Akmal Umar (2016), Rizki Novriyanti Zahara, Hajan Hidayat (2017), Cedaryana, Muchlis R. Luddin, Yetti Supriyati (2018), Harry Kurniawan, Heryanto (2019), Sebastiao Costa Rangel Sousa Simoes, Gde Riana, Made Subudi (2017) and I Ketut R. Sudiarditha, Dewi Susita, Tri Mulyani Kartini (2019), and I Ketut R. Sudiarditha, Dewi Susita, Tri Mulyani Kartini (2019).

\section{Effect of Career Development and Motivation on Employee Performance through Job Satisfaction}

Based on the analysis of career development variable descriptions, it shows that the employee placement indicator has the largest contribution to the formation of career development variables, namely employees are placed following education and job expertise. The motivation variable shows that the indicator of independent work provides the greatest contribution to the formation of the motivation variable, namely employees are not dependent on their work on their co-workers. Based on the analysis of job satisfaction variable descriptions, it shows that the dedication to work indicator gives the greatest value to the formation of job satisfaction variables, namely employees have high dedication in carrying out work so that every job is considered special. Based on the results of the path analysis, it shows that motivation and job satisfaction has an impact on improving employee performance. The employee performance variable shows that the initiative indicator makes a major contribution to the formation of employee performance variables, namely employees have a high initiative attitude at work.

Based on the results of the path analysis, it shows that career development and motivation on employee performance through job satisfaction do not have an impact on improving employee performance. The results of the research are not in line with research conducted by Nami Nasution, Emmy Mariatin, Siti Zahreni (2018), Ni Luh Putu Ariesta Angga Dewi, I Wayan Mudiartha Utama (2016), Ichlapio Fitrianto, Hasmin, Akmal Umar (2016), Rizki Novriyanti Zahara, Hajan Hidayat (2017), Cedaryana, Muchlis R. Luddin, Yetti Supriyati (2018), Ni Nengah Rupadi Kertiriasih, I Wayan Sujana, I Nengah Suardika 
(2018), and I Ketut R. Sudiarditha, Dewi Susita, Tri Mulyani Kartini (2019).

\section{Conclusions and Recommendations} Conclusion

Based on the results of the research analysis and discussion, it can be concluded as follows:

\section{a. Based on the analysis description:}

1) Career Development

Based on the analysis of career development variable descriptions, it shows that the employee placement indicator has the largest contribution to the formation of career development variables, namely employees are placed following education and job expertise.

2) Motivation

Based on the analysis of the description of the motivation variable, it shows that the indicator of independent work gives the greatest contribution to the formation of the motivation variable, namely that employees do not depend on their work on their colleagues.

3) Job Satisfaction

Based on the analysis of job satisfaction variable descriptions, it shows that the dedication to work indicator gives the greatest value to the formation of job satisfaction variables, namely employees have high dedication in carrying out work so that every job is considered special.

4) Employee Performance

Based on the results of the descriptive analysis of the employee performance variables, it shows that the initiative indicators make a major contribution to the formation of employee performance variables, namely employees have a high initiative attitude at work.

\section{b. Based on Path Analysis:}

1) Based on the results of the path analysis, it shows that career development and motivation have an impact on increasing job satisfaction.

2) Based on the results of the path analysis, it shows that career development and motivation have an impact on improving employee performance.

3) Based on the results of the path analysis, it shows that job satisfaction has an impact on improving employee performance.

4) Based on the results of the path analysis, it shows that career development and motivation on employee performance through job satisfaction have no impact on improving employee performance.
Vol: 1, Issue: 2

October $/ 2020$

https://ijbssrnet.com/index.php/ijbssr DOI: $10.47742 /$ ijbssr.v1n2p3

\section{Recommendations}

The research results are expected to be useful both theoretically and practically, namely:

a. For the development of science, it is hoped that this research can be useful for the development of science, especially HR management in the study of factors that affect employee performance.

b. This research is expected to be useful for PT. Jabar Jaya Perkasa in increasing sales and company development by considering:

1) The results of this study are expected to be used as a thoughtful contribution to PT. Jabar Jaya Perkasa, by paying attention to career development variables, especially for training and recruitment indicators which give the lowest value to the formation of career development variables, namely using companies having to often hold training for employee career development and company progress and companies only make recruitment according to job needs.

2) The results of this study are expected to be used as a thoughtful contribution to PT. Jabar Jaya Perkasa, by paying attention to motivation variables, especially for employee indicators, an important part of the organization, which gives the lowest score for the motivation variable, namely by paying attention to the company that employees are an important part of the success of achieving company goals. Therefore the company must provide rewards and punishments and provide outing activities so that employees feel part of the company.

3) The results of this study are expected to be used as a thoughtful contribution to PT. Jabar Jaya Perkasa, by paying attention to job satisfaction variables, especially for indicators of love in doing work which gives the lowest value to the variable of job satisfaction, that is, using which companies must be able to build love in doing work for their employees, have a sense of belonging.

The results of this study are expected to be used as a contribution of thought for PT. Jabar Jaya Perkasa, by paying attention to employee performance variables, especially for indicators of work quantity and knowing the work that gives the lowest value to employee performance variables, namely using employees having good knowledge at work so that it is very supportive of employees at work and employees must have high creativity at work thus supporting the achievement of employee performance by attending the training.

\section{References}

Agus, Dharma. (2003). Manajemen Supervisi: Petunjuk Praktis Bagi Para Supervisor.Edis i Revisi. Cetakan kelima. Jakarta: RajaGrafindo Persada.

Allen, NJ., Meyer PJ. And Smith CA. (1993). "Commitment to Organizations and Occupations: Extension and Test of a ThreeComponent Conceptualization", Journal of Applied Psychology, Vol. 78, No. 4. 
Ambar Teguh Sulistiyani dan Rosidah, (2003), Manajemen Sumber Daya Manusia, Graha Ilmu, Yogyakarta.

Basri, A. F. M., dan Rivai, V. (2005). Performance appraisal. Jakarta: PT Raja. Grafindo Persada.

Budi, Setiyawan dan Waridin. (2006). Pengaruh Disiplin Kerja Karyawan dan Budaya Organisasi Terhadap Kinerja di Divisi Radiologi RSUP Dokter Kariadi, Semarang: JRBI. Vol 2. No 2. Hal: 181-198

Cedaryana, Muchlis R. Luddin, Yetti Supriyati (2018). Influence of Work Discipline, Career Development and Job Satisfaction on Employee Performance Directorate General Research and Development of Ministry Research, Technology and Higher Education. International Journal of Scientific Research and Management (IJSRM). Volume 06, Issue 02, Pages EL-201887-96.

Corey, Gerald. (2005). Teori dan praktek dari konseling dan psikoterapi. Terjemahan oleh E. Koeswara. Jakarta: ERESCO.

Dini Yunita Ayundasari, Achmad Sudiro, Dodi Wirawan Irawanto (2017). Improving Employee Performance Through Work Motivation And Self-Efficacy Mediated By Job Satisfaction, Journal of Applied, Management (JAM), Volume 15 Number 4, December 2017.

Elliot, et.al, (2000). Educational Psychology: Effective Teaching, Effective learning, The Mc. Graw Hill Companies, America, 2000. Fauziah Nami Nasution, Emmy Mariatin, Siti Zahreni, (2018), The Influence of Career Development and Organizational Culture on Employee Performance, International Journal of Scientific Research and Management (IJSRM), Volume 06, Issue 01, Pages EL-2018-57-65

Ghozali, Imam. (2006). Aplikasi Analisis Multivariate dengan Program SPSS (Edisi Ke 4). Semarang:Badan Penerbit Universitas Diponegoro.

Gibson, Ivancevich, DonellyJr, (1985). Organisasi (Perilaku, Struktur, Proses), Jilid I Edisi Lima, Erlangga, Jakarta. Hair Anderson and Tatham Black, 1995, Multivariate Data Analysis, Prentice Hall, USA. Hani Handoko T, 2001, Manajemen Sumber Daya Manusia, BPFE, Yogyakarta.

Hasibuan, (2000), Manajemen Sumberdaya Manusia, Cetakan ke II, BPFE, UGM Yogjakarta.

Gibson, James L. et al. (1996). Organisasi: Perilaku, Struktur, Proses. Diterjemahkan oleh Ninuk Adriani. Jakarta: Binarupa Aksara. Handoko, T. Hani Handoko . (2003) . Manajemen . Edisi 2 . Penerbit BPFE Yogyakarta, Yogyakarta.

Harry Kurniawan, Heryanto (2019). Effect of Work Discipline and work Environment on Employee Performance with Work Motivation as an Intervening Variable in the Department of Tourism, Youth and Sport of Padang District. Archives of BusinessResearch, Vol.7, No.7.

Hasibuan, Malayu S.P (2007), Manajemen Sumber Daya Manusia Perusahaan, Bandung, PT. Bumi Aksa.

Henry Simamora, (2004), Manajemen Sumber Daya Manusia, Edisi III, STIE YKPN, Yogyakarta.

I Ketut R. Sudiarditha, Dewi Susita, Tri Mulyani Kartini (2019). Compensation And Work Discipline On Employee Performance With Job Satisfaction As Intervening. Trikonomika, Volume 18, No. 2, December 2019, Page. 80-87.

Ichlapio Fitrianto, Hasmin, Akmal Umar (2016). Pengaruh Motivasi, Disiplin, Dan Kepuasa Kerja, Terhadap Kinerja Karyawan PT. Bumi Rama NusantarA, Jurnal Mirai Management, Volume 1 Nomor 1, April-September 2016

Irianto, Yusuf, (2012). Tema-Tema Pokok Manajemen Sumber Daya Alam, Penerbit Insan Cendikiawan, Surabaya

L. Mathis, Robert dan John H. Jackson, (2006). Human Resource Management (Management Sumber Daya Manusia), Jakarta: salemba empat.

Makmun, Abin Syamsuddin. (2003). Psikologi Pendidikan. Bandung: Rosda Karya Remaja.

Mangkunegara, Anwar Prabu. (2005). Evaluasi Kinerja SDM, Cetakan Kedua Bandung: Rafika Aditama.

Mathis, Robert L, dan John Jackson, (2006), Manajemen Sumber Daya Manusia, Jakarta : PT. Salemba Empat.

Miner, John. B. (2005). Organizational Behavior: Performance and Productivity, First Edition, Random House, Inc. New York.

Mondy R Wayne. (2008). Manajemen Sumber Daya Manusia. Jakarta: Erlangga.

Natalia Susanto, (2019). Pengaruh Motivasi Kerja, Kepuasan Kerja, Dan Disiplin Kerja Terhadap Kinerja Karyawan Pada Divisi Penjualan Pt Rembaka. Agora Vol. 7, No. 12019

Ni Luh Putu Ariesta Angga Dewi, I Wayan Mudiartha Utama, (2016). Pengaruh Pengembangan Karir Terhadap Kinerja Karyawan Melalui Mediasi Motivasi Kerja Pada Karya Mas Art Gallery, E-Jurnal Manajemen Unud, Vol. 5, No.9, 2016:5494-5523

Ni Nengah Rupadi Kertiriasih, I Wayan Sujana, I Nengah Suardika . (2018). The Effect of Leadership Style to Job Satisfaction, Employee Engagement and Employee Performance (Study at PT. Interbat, Bali, Nusra, and Ambon). International Journal of Contemporary Research and Review. Vol. 9, Issue. 03, Page no: ME 20592-20600.

Noe, Raymond A, et al., (2003), Human Resources Management: Gaining a Competitive Advantage, 4 edition, McGrawHill/Irwin, New York

Rahmat Setiawan, Bustari Muchtar, Abror (2018). The Effects of Leadership Function, WorkMotivation and Job Satisfaction on Employee's Work Discipline at STIKes Fort De Kock Bukittinggi. Advances in Economics, Business and Management Research, volume 64.

Rizki Novriyanti Zahara, Hajan Hidayat (2017). Pengaruh Kepuasan Dan Disiplin Kerja Terhadap Kinerja Karyawan Bank Di Kota Batam. Journal of Applied Managerial Accounting. Vol. 1, No. 2, 2017, 150-156. 
Vol: 1, Issue: 2

October/2020

https://ijbssrnet.com/index.php/ijbssr DOI: $\underline{10.47742 / i j b s s r . v 1 n 2 p 3}$

Robbins, Stephen P. (2001). Perilaku Organisasi: Konsep, Kontroversi, Aplikasi, Jilid 1, Edisi 8, Prenhallindo, Jakarta.

Sastrohadiwiryo, Siswanto B. (2005). Manajemen Tenaga Kerja Indonesia Pendekatan Administrasi dan Operasional. Jakarta: PT Bumi Aksara.

Sebastiao Costa Rangel Sousa Simoes, Gde Riana, Made Subudi (2017). Pengaruh Motivasi Kerja Dan Disiplin Diri Terhadap Kepuasan Dan Kinerja Karyawan Kantor Kabupaten Ainaro Timor Leste. E-Jurnal Ekonomi dan Bisnis Universitas Udayana 6.10 (2017): 3463-3476.

Siagian, Sondang. P. (2006). Sistem Informasi Manajemen. Jakarta: PT. Bumi Aksara.

Siswanto, (2005), Pengantar Manajemen, Jakarta, Bumi Aksara.

Soeprihanto, John, (1996). Penilaian Kinerja dan Pengembangan Karyawan. Yogyakarta: BPFE UGM.

Sugiyono. (2005). Memahami Penelitian Kualitatif. Bandung: CV. Alfabeta.

Supranowo, (2017). The Influence of Working Environment Conditions, Compensation and Career Development on Employees' Working Motivation at an Indonesian Bank, Expert Journal of Business and Management, Volume 5, Issue 2, pp. 142-148, 2017

Winarno Surakhmad, (1990), Pengantar Penelitian Ilmiah, Tarsito, Bandung.

Zulkifli Rusby, Astri Ayu Purwati, Zulfadli Hamzah \& Hazwani Abdul Kadir, (2018), The Effect Of Career Development And Organizational Culture On Teacher Performance Through Job Satisfaction At National School Kebun Sireh Pulau Pinang, Preceding, $8^{\text {th }}$ International Management and Accounting Conference (IMAC8) 